\title{
Editorial: At the Half Way House: Ending poverty in 2015?
}

\author{
WENDY HARCOURT
}

According to José Antonio Ocampo, UN Under Secretary General for Economic and Social Affairs in his foreword to the 2006 Millennium Development Goals Report (http://unstats.un.org/unsd/mdg/Resources/Static/Products/Progress2006/MDGReport2006.pdf), the challenges the Millennium Development Goals (MDGs) face are staggering. His overall summary is bleak. So far very few milestones have been met. The disparities in progress, both among and within countries, are vast, and the poorest in remote rural areas are still beyond reach. According to the report, only Latin America and the Caribbean are approaching the MDGs and if today's trends continue, the world's 50 poorest countries have no chance of meeting the eight MDGs.

The question is not whether we want the goals to be met, but what we are doing to achieve them. The Millennium Project, headed by Jeffrey Sachs at Columbia University was set up as the guiding blue print The Millennium Report Investing in Development: A Practical Plan to Achieve the Millennium Development Goals (2005, http://www.unmillenniumproject.org/reports/index.htm) together with a slew of expert studies. The promotion of the MDGs is appealing. Sach's basic argument is that the MDG process is the opportunity in the coming decade to cut world poverty by half. Billions more people could enjoy the fruits of the global economy. Tens of millions of lives can be saved. Whatever one's motivation for attacking the crisis of extreme poverty - human rights, gender equality, environment, religious values, security, fiscal prudence and ideology - the practical solutions exist. The political framework is established. And for the first time, the cost is utterly affordable.

But it is not working. As Ocampo acknowledges, and as this journal issue shows, ending poverty in 2015 is not going to happen, despite all the efforts to collect statistics, and the technical talk about operationalizing, indicators and measurement. So why? To put it crudely, one cannot expect that a reductionist, technocratic and bureaucratic approach will 'fix' an infinitely complex world.

To begin with halving global poverty is not the same as halving poverty in each country. What kind of poverty are we talking about? How can figures and targets capture all that is needed to provide for a person's well-being? And when we move into the individual goals (http://www.undp.org/mdg/) there are more questions. How can education, 
for example, be the main measurement of women's empowerment? What happened to reproductive health and rights? Why are we talking so vaguely about HIV/AIDS? What happened to a goal on health systems? Where is a goal on corporate responsibility?

Even within the technocratic and bureaucratic manner framing the MDGs, there are other questions to be asked. Why are national reports for the South insisted upon for all targets and for the North only on Goal 8 (on partnership and development cooperation)? Who is doing the measuring? Why was a northern institute and Sachs chosen to lead the Millennium Project? How do all the many agendas of the UN fit neatly into the MDG process?

The MDG process leaves untouched the systemic causes of poverty while relying on 'campaigns' and 'experts' to calculate the figures and then sell the strategies to governments and civil society. They fail to grasp the meaning of poverty in the lives of the poor, in all its complexity, an existence that for most educated and middle class people carries incomprehensible levels of pain, violence and disorder endured and resisted through back-breaking courage and work. Measuring economic progress, introducing goals to be delivered by governments in blue prints to change the lives of 1.2 billion human beings in 15 years is almost meaningless when you consider what poor men, women and children have to live through in their communities.

The MDGs remain solidly in the tradition that the rich countries should do something for the poor countries by sending money, technical and medical knowledge, and writing off debts. They endorse rather than challenge international trade. They uphold the uneven development and the increase in global inequality fostered by global capitalism. They commend rather than question privatization of various resources needed for basic survival such as water. They ignore the reality of violence at individual and community levels, growing militarism, the wide spread displacements of people due to ecological disasters, the entrenchment of religious conservative fundamentalism and the disruptions of the market on
In a Monthly Review article, Samir Amin is blatant in his criticism that the MDGs 'are an apartheid on a world scale reproducing and deepening global polarization' (http://www.monthlyreview.org/0306amin.htm).

Yet, for many of us working in the development community we cannot afford to dismiss the MDGs. They are shaping the contours of our work within the development discourse on poverty today. The goal to end poverty is a major focus for most of us whether we work in the UN, research institutes, government, NGOs, charities or social movements. Therefore, as the MDGs meet their half-way mark, we have devoted this issue of the 50th anniversary journal volume to a deeper, critical look at poverty. Writers from multilateral and national development aid agencies, the research community, NGOs and social movements map the current thinking, action and critical concerns around poverty.

In bringing together a broad spectrum of approaches, we try to go below the undoubted good will of all concerned to the underlying assumptions behind different strategic approaches, analysis and rhetoric internationally, nationally and locally. The journal approach is markedly not that 'we have the solution, all we need is money and action'. For the writers here poverty is a problematic concept, with different meanings and contexts according to the diverse paradigms found in development policy, research institutions as well as economic and social justice movements living and working with the realities of the poor.

Along this line a sobering statement was sent to me by the Associate Editor Nicola Bullard from The Movement for National Land and Agricultural Reform, (Monlar) Sri Lanka (http://www.geocities.com/monlarslk/) who work and live with the poor in Sri Lanka. In their statement, they question if the MDGs and the world focus on poverty by such alliances as the Global Call Against Poverty (http://www.whiteband.org/) have any meaning at all for the paddy farmers, plantation workers, fishermen and women struggling for survival. They argue, not unreasonably, that when the MDGs in 2015 are not reached, the global partnership of poor and rich, companies, governments and international institutions will agree that 
reducing poverty is a terribly difficult task, and new targets will be set. Living and working with the poor in the Global South, Monlar and other social movements see the solution not in setting new policies and better targets, but in looking at where the wealth is and who controls it. As Monlar points out, if we want poverty to end then we need to look at the policies that allow Anchor, Nestle and Maliban to sell powdered milk, destroying children's health and farmer's livelihoods. We need to challenge Unilever that controls the market for many basic products used daily like soap and toothpaste and thereby prevents local production with natural products. And we need to look at how despite 60 years of talking about poverty, the World Bank has not reduced poverty but rather increased inequality through projects pushing governments to give freehold titles to farmers so that they sell their land and move into slums, producing deeper cycles of poverty.

The journal aims to explore the underlying causes of economic, social inequalities and injustice, while at the same time illustrate the major difficulties that must be faced to overcome poverty. The focus of the issue is largely on the experience of poverty among communities in the Global South although some articles address the issue of the marginalized poor in the Global North. In studies on globalization, chronic poverty, participation, charity, human rights, fundamentalism, violence, HIV/AIDS and the experiences of poverty in Kenya, Sudan, Pakistan, Bangladesh, India, El Salvador, indigenous communities in Australia, unemployed in North America and migrants in Europe, the journal issue attempts to cut through the rhetoric around poverty, some of it generated by the MDGs and look at the harsh realities as they are lived.

Robert Chambers sets us the challenge: 'Poverty may never be made history. But we can ask whether a precondition for its sharp reduction is that powerful professionals become more participatory and get closer to and learn more from those who live their lives in poverty; and then act on what they experience, learn and feel'. 